\title{
Breakfast habit and nutritional status of undergraduates in Ekiti state, Nigeria
}

\author{
Oladapo Adenike Adesola ${ }^{1,}$, Roland-Ayodele Motunrayo Ayodeji ${ }^{1}$, Quadri Jelili Akorede ${ }^{2}$, \\ Omogbenigun Oluranti ${ }^{1}$
}

${ }^{1}$ Department of Nutrition and Dietetics, Rufus Giwa Polytechnic, PMB 1019, Owo, Ondo State, Nigeria

${ }^{2}$ Department of Nutrition and Dietetics, Ogun State College of Health Technology, Ilese-Ijebu, Ogun State, Nigeria

\author{
Email address: \\ solape201@yahoo.com (Oladapo A. A.)
}

\section{To cite this article:}

Oladapo Adenike Adesola, Roland-Ayodele Motunrayo Ayodeji, Quadri Jelili Akorede, Omogbenigun Oluranti. Breakfast Habit and Nutritional Status of Undergraduates in Ekiti State, Nigeria. Science Journal of Public Health. Vol. 2, No. 4, 2014, pp. $252-256$.

doi: $10.11648 /$ j.sjph.20140204.11

\begin{abstract}
The study was carried out to assess the breakfast consumption habit and nutritional status of undergraduates in Ekiti State, Nigeria. Two hundred and fifty students comprising of 186 female and 64 male were randomly selected in two higher institutions. A self administered questionnaire which elicits information on socio-demographic data and breakfast habit of the students was used. Nutrients intake of the respondents was assess using 24 hour dietary recall while the Body Mass Index (BMI) was used to assess the nutritional status of the respondents. The result revealed that $76.2 \%$ of the respondents were female while $23.8 \%$ were male. Slightly above average (52.8\%) were within the age range of $16-20$ years while $36.8 \%$ received more than $\square 10,000$ as feeding allowances. In general, $52 \%$ of the students reported not to be taking breakfast on the day of the survey and $40.8 \%$ attributed this to insufficient feeding allowances. Nutritional status assessment showed that there was no significant difference $\left(\mathrm{X}^{2}=4.16 ; \mathrm{P}=0.24\right)$ between breakfast skipping and BMI. The 24 hour dietary analysis showed that there was a significant $(\mathrm{P}<0.05)$ difference between the mean protein and fat intake of breakfast skippers and eaters. The mean nutrients intake of breakfast skippers and eaters were; energy (2315.4kcal vs $2229.6 \mathrm{kcal})$, protein $(52.6 \mathrm{~g} \mathrm{vs} 58.4 \mathrm{~g})$, fat $(42.1 \mathrm{~g}$ vs $33.0 \mathrm{~g})$, carbohydrate $(324.3 \mathrm{~g}$ vs $306.3 \mathrm{~g}$ ), iron $(12.4 \mathrm{mg}$ vs $12.6 \mathrm{mg})$, and calcium $(1106.2 \mathrm{mg}$ vs $1157.9 \mathrm{mg})$. The study concluded majority of the students' skip breakfast, a reflection of insufficient feeding allowances, busy schedule and weight control measures. The study then recommends that parents should increase the feeding allowances of their children that are in tertiary institutions.
\end{abstract}

Keywords: Breakfast Habit, Nutrition, Body Mass Index, Undergraduate

\section{Introduction}

Eating behaviors, such as consuming breakfast has been associated with intakes of nutrients as well as body weight [1]. Studies have concluded that breakfast consumption has an important impact on nutritional status $[2,3]$, it has been suggested that breakfast meal is an important dietary factor for energy regulation. Increased snacking, sedentary lifestyle and obesity have been found to be common among those who skip breakfast than the breakfast eaters $[4,5]$. Breakfast consumption was also suggested to have potential effect on the treatment of binge eating disorder [6]. Furthermore, research has linked the consumption of breakfast with adolescents' mental and physical health [7,8]. Students who consumed breakfast were likely to experience mental stress and were more likely to get better grades and better school attendance. On the other hand, skipping breakfast has been linked with adverse effect on the cognition, school attendance, psychosocial function, and mood in young adult and children [9]. Factors such as emergence of fast food outlets, shopping malls, convenience stores and high cost of healthy meal has contributed to the unhealthy eating habits among university students [10], and lack of knowledge of healthy food choices may negatively affect nutritional status and eating habits [2]. University students often pay little attention to breakfast, with some missing breakfast because it takes too much time to prepare [11]. In Nigerian universities, it has been observed that most students lack fund or divert their pocket or feeding money to other frivolities and so skip meals including breakfast and there are no central feeding 
facilities for students in the university campuses, so the students are forced to take responsibility for their feeding. [12].These can therefore lead to malnutrition, if the students are not educated properly on the importance of adequate nutrients intake. Even though the association between breakfast habit and obesity are widely studied, few or no research has been conducted in the study area. To this end, this study asses the relationship between the breakfast consumption habit and nutritional status of the undergraduates in Ekiti state, Nigeria.

\section{Material and Methods}

This study was a descriptive survey assessing the breakfast consumption habit and nutritional status of students (undergraduates) in Ekiti State. A total of 250 students from two public tertiary institutions were sampled using a convenience sampling method. Informed consents were sought from the young adult (students) who are willing to participate prior to the collection of the data. Semi structured self administered questionnaire was used to obtained information on socio-demographic, breakfast habit (breakfast was defined as any foods or drinks eaten between the hour of $8 \mathrm{am}$ and $10 \mathrm{am}$ ) and factors associated with breakfast skipping. Anthropometric measurements such as, weight and height were obtained to assess the nutritional status. Height was measured to the nearest $0.1 \mathrm{~cm}$ using wall meter rule, while their weight was measured with light clothing on using a portable bathroom scale. The WHO [13] was used to classify subjects as underweight, normal weight, overweight and obese. The 24 hour dietary recall method was used to assess the nutrients intake of the students. The students were asked to recall all the foods, snacks and beverages consumed in the previous 24 hour (hr) prior to the interview. Food intakes were converted to nutrients using food composition table. All statistical analysis were carried out using SPSS for window version 16.0, categorical variables results are presented as the frequency and percentage while continuous variables results are presented as the mean $\pm \mathrm{SD}$. Chisquared test was used for categorical variables while independent t-test was used for continuous variables. Significance level was set at $\mathrm{p}<0.05$.

\section{Results}

Table 1 showed the socio demographic characteristics of the undergraduates. Approximately, 74\% were female while $26 \%$ were male, $52.8 \%$ were within the age range of $16-20$ years and majority (92.8\%) were single while $51.2 \%$ received between $\$ 2000$ - $\$ 9000$ as feeding allowances. Table 2 showed the breakfast habit and factors associated with breakfast skipping, slightly over half (52.0\%) skips meal. Regarding the pattern of skipping, $21.5 \%$ skipped meal once per week while $30.8 \%$ skipped meal three times per week. The major factors identified for skipping breakfast were insufficient feeding allowances $(40.8 \%)$ and busy schedule (27.7\%). The anthropometric measurements are described in table 3, Statistically there was a significant $\left(\mathrm{X}^{2}=8.69 ; \mathrm{P}<0.05\right)$ difference between the nutritional status of male and female who skipped breakfast, $11.1 \%$ of male who skipped breakfast were underweight while $33.3 \%$ had normal weight status. Approximately $60 \%$ of female who skipped breakfast had normal weight status while $7.4 \%$ were obese. For breakfast eaters, $42.9 \%$ (male) and $72.8 \%$ (female) had normal weight status while $50.0 \%$ and $10.9 \%$ male and female students were overweight respectively. Table 4 showed the nutrients intake of the undergraduates. The mean energy intake was $2315.4 \mathrm{kcal} \pm 316.1$ and $2229.6 \mathrm{kcal}$ \pm 499.1 for breakfast skippers and eaters respectively; also protein intake was $52.6 \mathrm{~g} \pm 11.8$ and $58.4 \mathrm{~g} \pm 19.3$ for breakfast skippers and eaters respectively. There was a significant $(\mathrm{P}<0.05)$ difference between the fat intake of breakfast skippers (42.1 $\pm 9.9 \mathrm{~g})$ and breakfast eaters $(33.0 \pm 6.7 \mathrm{~g})$.Calcium intake was $1106.2 \mathrm{mg}$ and $1157.9 \mathrm{mg}$ for breakfast skippers and eaters respectively.

\section{Discussion}

This research assess the nutritional status as well as the breakfast habit of the undergraduates in Ekiti State, Nigeria as breakfast was believed to be an important meal of the day, providing energy and increase productivity during the morning [14]. The main finding of this study indicates that slightly above average (52\%) skip breakfast or had infrequent breakfast consumption. This finding was higher in comparison with previous studies; the study conducted among undergraduates in university in Kuala, Malaysia showed that $29.2 \%$ skipped breakfast [5], similar study conducted by Tanaka et al. [15] showed that $35.4 \%$ skipped breakfast meal, $31.5 \%$ of adolescents skipped breakfast in a study conducted by Priya et al. [16], the prevalence of breakfast skipping among students studying traditional Chinese medicine and Mongolian medicine was 22.7\% [17], while it was $44.9 \%$ among undergraduates of Federal University of Agriculture Abeokuta, Nigeria [18]. Quite a high number of female participants skipped breakfast more than male counterpart, perhaps the female are more concern with their body image, that is, fear of being overweight and obese. This is similar with the previous studies that linked meals skipping to concern about body image among adolescent girls [19-22]. The reasons cited by the students for skipping breakfast were inadequate feeding allowances or pocket money and busy schedules. Inadequate monthly allowances may lead to missed meals and intake of low nutritional value foods which may in turn impair cognitive function. Rampersaaud et al. [9]; Pollitt and Mathews [23] assert that breakfast consumption improves school attendance and enhances the quality of the students' diets. Though several research has linked breakfast skipping to overeating and obesity [5, 22, 24-25], this study revealed that there was no significant difference $\left(X^{2}=4.16 ; \quad P=0.24\right)$ between breakfast skipping and nutritional status of the 
undergraduates. This study contradict the findings of Harding et al. [26], they found an association between breakfast skipping and obesity among adolescents in the United Kingdom but this study is consistent with other studies in children and adolescents from Australia and Saudi Arabia that there was no significant association between infrequent breakfast consumption, and body composition in male and female adolescents [27, 28]. In this study, some of the breakfast skippers still have normal nutritional status just like those that did not skipped; this may mean that breakfast skippers have an alternative means, such as eating fast-food meal which tend to be high in sugar, fat and low in fiber. Breakfast skippers have higher energy and fat intake, lower intake of calcium and iron than breakfast eaters, breakfast skippers are reported to have higher daily intakes of energy, fat, cholesterol, lower intakes of vitamins, and minerals in contrast to breakfast eaters, thereby increasing the likelihood of gastrointestinal disease later in life [29].

\section{Conclusion and Recommendation}

The study concluded majority of the students' skip breakfast, an indication of insufficient feeding allowance/ pocket money, busy schedule and weight control measures. The study then recommends that parents should improve or increase the feeding allowances of their wards that are in higher learning institutions.Also, undergraduates should be educated about healthy eating behaviors in order to prevent risk of obesity and related metabolic consequences in future.

\section{Acknowledgment}

The authors would like to thank the students who participated in this study for their cooperation with us.

\section{Authors' Contributions}

OAA conceived, designed the study and wrote the first draft, RMA and OO collected the data. OAA supervised the data collection. QJA performed the statistical analysis. All authors edited and approved the final version of the manuscript.
Table 1. Socio-demographic data of the respondents.

\begin{tabular}{lcc}
\hline Characteristics & Frequency & Percentages (\%) \\
\hline Sex & 64 & \\
Male & 186 & 25.6 \\
Female & & 74.4 \\
Age & 132 & \\
16-20yrs & 92 & 52.8 \\
21-25yrs & 26 & 36.8 \\
26yrs and above & & 10.4 \\
Marital Status & 18 & \\
Married & 232 & 7.2 \\
Single & & 92.8 \\
Pocket Money/Semester & 30 & \\
<\#2000 & 30 & 12.0 \\
\#2000- \#3000 & 54 & 12.0 \\
\#4000- \#6000 & 44 & 21.6 \\
\#7000-\#90000 & 92 & 17.6 \\
Z\#10000 & & 36.8 \\
\hline
\end{tabular}

Table 2. Respondents' breakfast habit and the associated factors.

\begin{tabular}{lccc}
\hline Variables & Male & Female & Total \\
\hline Do you skip breakfast? & & & \\
Yes & $36(27.7)$ & $94(72.3)$ & $130(52.0)$ \\
No & $28(23.3)$ & $92(76.7)$ & $120(48.0)$ \\
How many times do & & & \\
you skip breakfast/ week? & & & \\
Once & $9(32.1)$ & $19(67.9)$ & $28(21.5)$ \\
Twice & $10(35.7)$ & $18(64.3)$ & $28(21.5)$ \\
Thrice & $13(32.5)$ & $27(67.5)$ & $40(30.8)$ \\
More than thrice & $4(11.8)$ & $30(88.2)$ & $34(26.2)$ \\
Reasons for skipping & & & \\
Breakfast & & & \\
Busy schedule & $10(27.8)$ & $26(72.2)$ & $36(27.7)$ \\
Fasting & $0(0.0)$ & $19(100.0)$ & $19(14.6)$ \\
Insufficient feeding & $25(47.2)$ & $28(52.8)$ & $53(40.8)$ \\
allowances & $0(0.0)$ & $13(100.0)$ & $13(10.0)$ \\
Health reasons & $1(11.1)$ & $8(88.9)$ & $9(6.9)$ \\
Lack of appetite & & &
\end{tabular}

Values are $\mathrm{n}(\%)$

Table 3. Breakfast habit and nutritional status of the respondents.

\begin{tabular}{|c|c|c|c|c|c|c|}
\hline & \multicolumn{2}{|c|}{ Breakfast skippers } & \multicolumn{2}{|c|}{ Breakfast eaters } & \multicolumn{2}{|c|}{ Total } \\
\hline & Male & Female & Male & Female & Male & Female \\
\hline $\begin{array}{l}\text { Underweight } \\
\left(<18.5 \mathrm{~kg} / \mathrm{m}^{2}\right)\end{array}$ & $4(11.1)$ & $20(21.3)$ & $0(0.0)$ & $8(8.7)$ & $4(6.3)$ & $28(15.1)$ \\
\hline \multicolumn{7}{|l|}{ Normal } \\
\hline $\begin{array}{c}\text { Overweight } \\
\left(25-29.9 \mathrm{~kg} / \mathrm{m}^{2}\right)\end{array}$ & $16(44.4)$ & $16(17.0)$ & $14(50.0)$ & $10(10.9)$ & $30(46.9)$ & $26(14.0)$ \\
\hline \multirow[t]{2}{*}{$\left(\geq 30 \mathrm{~kg} / \mathrm{m}^{2}\right)$} & $4(11.1)$ & $7(7.4)$ & $2(7.1)$ & $2(2.2)$ & $6(9.4)$ & $9(4.8)$ \\
\hline & \multicolumn{2}{|c|}{$X^{2}=8.69 ; P<0.05$} & \multicolumn{2}{|c|}{$\mathrm{X}^{2}=6.89 ; \mathrm{P}>0.05$} & \multicolumn{2}{|c|}{$\mathrm{X}^{2}=14.19 ; \mathrm{P}<0.05$} \\
\hline
\end{tabular}

Values are $\mathrm{n}(\%)$

Generally, there was no significant difference $\left(\mathrm{X}^{2}=4.16 ; \mathrm{P}=0.24\right)$ between breakfast skipping and nutritional status 
Table 4. Mean nutrients intake of the respondents.

\begin{tabular}{ccc}
\hline Nutrients & Breakfast skippers & Breakfast eaters \\
\hline Energy $(\mathrm{kcal})$ & $2315.4 \pm 316.1$ & $2229.6 \pm 499.1$ \\
Protein $(\mathrm{g})^{*}$ & $52.6 \pm 11.8$ & $58.4 \pm 19.3$ \\
Fat $(\mathrm{g})^{*}$ & $42.1 \pm 9.9$ & $33.0 \pm 6.7$ \\
Carbohydrate $(\mathrm{g})$ & $324.3 \pm 127.4$ & $306.3 \pm 128.3$ \\
Iron $(\mathrm{mg})$ & $12.4 \pm 4.1$ & $12.6 \pm 4.4$ \\
Calcium $(\mathrm{mg})$ & $1106.2 \pm 144.5$ & $1157.9 \pm 177.5$ \\
\hline
\end{tabular}

Values are expressed as the means \pm standard deviation

*Independent $t$-test showed a significant difference at $\mathrm{P}<0.05$ between two groups.

\section{References}

[1] Obbagy JE, Patricia CM, Eve VE. Breakfast Consumption, Body Weight, and Nutrient Intake: A Review of the Evidence. Nutrition Insight 45, 2011. U.S. Department of Agriculture Center for Nutrition Policy and Promotion

[2] Gan WY, Mohd NM, Zalilah MS, Hazizi AS. Differences in eating behaviours, dietary intake and body weight status between male and female Malaysian university students. Mal J Nutr. 2011, 17(2):213-228.

[3] Huda N, Ruzita A. Preliminary survey on BMI profile among USM main campus students.Pak.J.Nutr, 2011, 9:125-127.

[4] Keski-Rahkonen A, Kaprio J, Rissanen A, Virkkunen M, Rose RJ. Breakfast skipping and health-compromising behaviours in adolescents and adults. Eur J Clin Nutr , (2003) 57: 842853

[5] Moy FM, Johari S, Ismail Y, Mahad R, Tie FH, Wan Ismail WMA. Breakfast Skipping and It's Associated Factors among Undergraduates in a Public University in Kuala Lumpur. Mal J Nutr, (2009), 15(2): 165 - 174.

[6] Masheb RM, Grilo CM Eating patterns and breakfast consumption in obese patients with binge eating disorder. Behaviour Research and Therapy, 2006, 44, 1545-1553.

[7] O'Sullivan TA, Robinson M, Kendall GE, Miller M, Jacoby P, Silburn SR, Oddy WH: A good-quality breakfast is associated with better mental health in adolescence. Public Health Nutrition, 2008, 12, 249-258.

[8] Pearson N, Biddle SJH, Gorely T. Family correlates of breakfast consumption among children and adolescents. A Syst. Rev., Appetite, 2009, 52: 1-7.

[9] Rampersaud GC, Pereira MA, Girard BL, Adams J, Metzl JD Breakfast habits, nutritional status, body weight and academic performance in children and adolescents. J Am Diet Assoc, 2005, 105: 743-760.

[10] King DE, Mainous Iii AG, Geesey ME. Turning back the clock: Adopting a healthy lifestyle in middle age. The American Journal of Medicine, 2007, 120, 598-603.

[11] Zeng YC, Li SM, Xiong GL, Su HM, Wan JC: Influences of protein to energy ratios in breakfast on mood, alertness and attention in the healthy undergraduate students. Health 2011, 3(6):383-393.
[12] Achinihu G. Nutritional status of university students in south eastern state of Nigeria. Journal of research in National development, 2009, vol. 7:2. http://dx.doi.org/10.4314/jorind.v7i2.50966

[13] World Health Organization (WHO) Physical Status: the use and interpretation of anthropometry. Technical Report Series. Report of a WHO Expert Committee No. 854, 1995. World Health Organization, Geneva.

[14] Chapman GE, Melton CL, Hammond GK. College and university students' breakfast consumption pattern: Behaviours, Beliefs Motivations and personal and environmental influences. Can J Diet Res, 1998, 59(4) 176$182 \mathrm{~s}$

[15] Tanaka M, Mizuno K, Fukuda S, Shigihara Y, Watanabe Y. Relationships between dietary habits and the prevalence of fatigue in medical students. Nutrition, 2008, 24: 985-989.

[16] Priya RD, Theresa AN, Carol EO, Debra RK, John DR, Susan C. The relationship of breakfast skipping and type of breakfast consumption with nutrients intake and weight status in children and adolescents: The national health and nutrition examination survey 1999-2006. Journal of the Academy of Nutrition and Dietetics, 2010, 110(6) 869-878.

[17] Sun J, Yi H, Liu Z, Wu Y, Bian J, Wu Y, Eshita Y, Li G, Zhang Q, Yang Y. Factors associated with skipping breakfast among Inner Mongolia Medical students in China. Public Health, 2013, 13:42. Available at http://www.biomedcentral.com/1471 2458/13/42 .doi: 10.1186/1471-2458-13-42.

[18] Adesina AE. Food consumption pattern and nutritional knowledge of undergraduates in a selected college in Federal University of Agriculture, Abeokuta. Unpublished Thesis. 2013, Department of Nutrition and Dietetics, Federal University of Agriculture, Abeokuta, Nigeria.

[19] Chin YS, Mohd Nasir MT. Eating behaviours among female adolescents in Kuantan district, Pahang, Malaysia. Pakistan journal of nutrition, 2009, 8(4) 425-432.

[20] Calderon LL, Yu Ck S, Jambazian P. Dieting practices in high school students. J. Am. Diet Assoc.2004, 104 (9) 1369-1374

[21] Sjoberg A, Hallberg L, Hoglund D, Hulthen L. Meal pattern, food choice, nutrient intake and lifestyle factors in the Goteborg adolescents study. Euro. J. Clin. Nutr. 2003, 57 (12): $1569-1578$

[22] Onyiriuka AN, Umoru DD, Ibeawuchi AN. Weight status and eating habits of adolescent Nigerian urban secondary school girls. South African journal of child health, 2013, 7(3) 108112.

http://www.sajch.org.za/index.php/SAJCH/article/view/529/4 54. Accessed 24 apr.2014,doi:10.7196/sajch.529

[23] Pollitt E, Mathews R. Breakfast and cognition: An integrative summary. Am. J. Clin. Nutr., 1998, 67 (Suppl.): 804S-13S.

[24] Ma YS, Bertone ER, Stanek EJ, Reed GW, Herbert JR, Cohen NL, Merriam PA, Ockene, IS. Association between eating patterns and obesity in a free living US adult population. Am J Epidemiol, 2003, 158: 85-92.

[25] Fujiwara T. Skipping breakfast is associated with dysmenorrhea in young women in Japan. Int J Food Sci Nutr, 2003, 54(6): 505-509. 
[26] Harding S, Teyhan A, Maynard MJ, Cruickshank JK. Ethnic differences in overweight and obesity in early adolescence in the MRC DASH study: the role of adolescent and parental lifestyle. Int J Epidemiol, 2008, 37: 162-172.

[27] William P. Breakfast and the diets of Australian children and adolescents: an analysis of data from the 1995 National Nutrition Survey. Int J Food Sci Nutr, 2007, 58: 201-216.
[28] Abalkhail B, Shawky S. Prevalence of daily breakfast intake, iron deficiency anaemia and awareness of being anaemic among Saudi school students. Int J Food Sci Nutr, 2002, 53: 519-28.

[29] Timlin MT, Pereira MA. Breakfast frequency and quality in the etiology of adult obesity and chronic diseases. Nutr Rev 2007, 65:268-281. 